\title{
SB242084, flumazenil, and CRA1000 block ethanol withdrawal- induced anxiety in rats
}

\author{
Darin J. Knapp ${ }^{a, c},{ }^{*}$, David H. Overstreet ${ }^{a, c}$, Sheryl S. Moy ${ }^{a, c}$, and George R. Breese ${ }^{a, b, c, d}$ \\ aBowles Center for Alcohol Studies, CB\#7178, University of North Carolina at Chapel Hill, Chapel \\ Hill, NC 27599, USA \\ bUNC Neurosciences Center, University of North Carolina at Chapel Hill, Chapel Hill, NC 27599, \\ USA \\ 'Department of Psychiatry, University of North Carolina at Chapel Hill, Chapel Hill, NC 27599, USA \\ dDepartment of Pharmacology, University of North Carolina at Chapel Hill, Chapel Hill, NC 27599, \\ USA
}

\begin{abstract}
Anxiety-like behaviors are integral features of withdrawal from chronic ethanol exposure. In the experiments in the current study, we tested the hypothesis that anxiety can be regulated independently of other withdrawal signs and thus may be responsive to selective pharmacological agents. For 17 days, rats were fed ethanol (8-12 g/kg/day) in a liquid diet. Between 5 and $6 \mathrm{~h}$ after cessation of ethanol treatment, rats were tested in either the social interaction or plus-maze test of anxiety-like behavior after treatment with drugs hypothesized to have anxiolytic action. SB242084, flumazenil, and CRA1000 - antagonists for 5-hydroxytryptamine (serotonin) (5-HT) 2C (5-HT 2 ),

benzodiazepine, and corticotropin-releasing factor type $1\left(\mathrm{CRF}_{1}\right)$ receptors, respectively-attenuated decreased social interaction without concomitant effects on activity measures. In contrast, ifenprodil, MDL 72222, and zolpidem - antagonists for $N$-methyl-o-aspartate (NMDA) and 5-HT 3 receptors, and agonist for benzodiazepine type 1 receptors, respectively—did not share this effect. Results for SB242084, flumazenil, and ifenprodil in the elevated plus-maze test were comparable to those in the social interaction test. These results support the suggestion that multiple neuronal systems $\left(\mathrm{CRF}_{1}\right.$, $5-\mathrm{HT}_{2 \mathrm{C}}$, and benzodiazepine receptors) contribute to the ethanol withdrawal sign of decreased social interaction. Furthermore, the selective effects of pharmacological agents on social interaction seem to indicate that this behavior can be dissociated from other signs. Because anxiety may be a complicating factor in alcohol withdrawal and relapse, future studies of this type are needed to provide focus for the effort to define selective and novel antianxiety agents for these disorders.
\end{abstract}

\section{Keywords}

5-HT $2 \mathrm{C}$; Benzodiazepine antagonist; Corticotropin-releasing factor; Ethanol withdrawal syndrome; Anxiety-like behavior; Social interaction test 


\section{Introduction}

Studies of antianxiety-like actions of pharmacological agents in animals undergoing ethanol withdrawal are challenging, in part because of the co-occurrence of potentially confounding signs, such as tremor, suppressed activity/locomotion, and seizures. Nonetheless, the results of many previous reports show that withdrawal from chronic ethanol treatment results in anxiety-like behavior in both human beings (Koob \& Le Moal, 1997; Meyer, 1986; Naranjo $\&$ Sellers, 1985) and animal models (Baldwin et al., 1991; Criswell \& Breese, 1993; File et al., 1989; Knapp et al., 1998; Moy et al., 1997, 2000). The mechanisms mediating anxiety-like behavior have not been definitively established.

Although benzodiazepines such as diazepam have long been known to be helpful in attenuating anxiety during ethanol withdrawal, it is generally understood that significant tolerance and dependence may result from their use. Novel benzodiazepine agents are actively being pursued as possibly safer treatments [see, for example, June et al. (1998a, 1998b)]. Like benzodiazepines, agents directed at the $N$-methyl-p-aspartate (NMDA) receptor [e.g., dizocilpine maleate (MK-801)] have also met with difficulties, given evidence for neurotoxicity or lack of efficacy on anxiety-like behavior (Criswell et al., 1994; Gatch et al., 1999; Horváth et al., 1997). However, NMDA receptor-modulatory sites (e.g., ifenprodil binding site or the strychnine-insensitive glycine recognition site) may present safer and more promising targets (Snell et al., 2000; Yang et al., 1996). Novel agents acting on corticotropinreleasing factor type $1\left(\mathrm{CRF}_{1}\right)$, 5-hydroxytryptamine (serotonin) (5-HT) $2 \mathrm{C}\left(5-\mathrm{HT}_{2} \mathrm{C}\right)$, or 5HT 1A (5-HT 1A $_{\text {A }}$ receptors (Chaki et al., 1999; File et al., 1993b; Griebel et al., 1997; Kennett et al., 1996, 1997; Schaffer \& Naranjo, 1998; Wood et al., 2001) also offer promise for safely attenuating the anxiety of ethanol withdrawal. For example, the 5-HT $\mathrm{HA}_{1 \mathrm{~A}}$ receptor agonist buspirone has made the transition from animal studies (File et al., 1993b; Lal et al., 1991) to human beings and is recommended for treatment of chronic anxiety in alcoholism (Schaffer \& Naranjo, 1998).

In the current series of experiments, we tested potential antianxiety agents, acting at a range of neurotransmitter receptors $\left(\mathrm{CRF}_{1}, 5-\mathrm{HT}_{2} \mathrm{C}\right.$, and 5- $\mathrm{HT}_{3}$ receptors; the benzodiazepine type 1 receptor; and the polyamine-site on the NMDA receptor), in a modification of the social interaction test. The social interaction test is a simple and elegant animal model that has been used in studies of a host of anxiogenic or anxiolytic drugs of various classes [see, for example, Costall et al. (1988), Dunn et al. (1989), File et al. (1996, 1999), and Overstreet et al. (2000)] and ethanol or benzodiazepine withdrawal [see, for example, Andrews et al. (1997), File (1997), File et al. (1989, 1993a, 1993b), and Kampov-Polevoy et al. (2000)]. In the current studies, we attempted (1) to assess anxiety-like behavior with the social interaction test after withdrawal from shorter-term ethanol drinking (17 days), in which low-to-moderate levels of ethanol withdrawal severity are manifest; (2) to confirm the induction of anxiety-like behavior with a second established animal model; and (3) to determine whether this approach could generate anxiety-like behavior that was separable (operationally/pharmacologically) from effects of ethanol withdrawal on locomotor behavior. These objectives were based, in part, on the premise that anxiety exists in various forms that are differentially elicited in different anxiety models and that manipulation of specific receptors in brain can alter the expression of specific anxiety states. Positive results from this type of behavioral study would set the stage for future complementary studies to identify neuroanatomic substrates of the anxiety component of withdrawal and effective pharmacological actions. 


\section{Materials and methods}

\subsection{Subjects}

For 1 week before ethanol treatment, groups of 40, adult male, Sprague-Dawley rats (each weighing between 160 and $180 \mathrm{~g}$ ), purchased from Charles River (Raleigh, NC), had ad libitum access to food and water in a temperature-and humidity-controlled environment on a normal 12-h light/12-h dark cycle, with lights on at 0900 . For each group of 40 rats, 8 received control diet, and 32 received an ethanol-containing diet. After receiving this diet for 17 days, the rats were withdrawn and treated with vehicle or one of several treatments described below. Animal care and use was approved by the Institutional Animal Care and Use Committee at the University of North Carolina as per the Guide for the Care and Use of Laboratory Animals (Institute of Laboratory Animal Resources, Commission on Life Sciences, National Research Council, 1996).

\subsection{Drug treatments}

Ethanol (from 95\% stock; Aaper, Shelbyville, KY) was administered by means of a nutritionally complete liquid diet. This standard dietary ethanol procedure involves administration of 7\% [weight/volume (wt./vol.)] ethanol in a lactalbumin/dextrose-based diet for 17 days, during which time rats generally consume ethanol at 8 to $12 \mathrm{~g} / \mathrm{kg} /$ day and achieve blood ethanol levels up to $200 \mathrm{mg} / \mathrm{dl}$ (Criswell \& Breese, 1993; Frye et al., 1981; Knapp et al., 1998). The diet was nutritionally complete (with concentrations of vitamins, minerals, and other nutrients derived from ICN Research Diets) and calorically balanced (with dextrose) across ethanol-treated rats and control rats. Intake matching was achieved by giving the control diet-treated rats a volume of diet equivalent to the average intake of the ethanol diet-treated rats the day before. Both groups readily gained weight during the ethanol exposure period.

In the first series of experiments, specific receptor antagonist or agonist treatments were given after removal of chronic ethanol diet exposure on day 17. Each rat received only one of the drugs and was tested only one time during withdrawal. The maximal withdrawal syndrome resulting from this procedure (including anxiety-like behavioral responses) occurs 5 to $7 \mathrm{~h}$ after removal of the ethanol diet from the rats' cages (Criswell \& Breese, 1993; Knapp et al., 1998; Moy et al., 2000). Attempts to block behavioral changes induced by withdrawal during this period were made with intraperitoneal injections of the $5-\mathrm{HT}_{2 \mathrm{C}}$ receptor antagonist SB242084 (6-chloro-5-methyl-1-[6-(2-methylpyridin-3-yloxy) pyridin-3-yl carbomyl] indoline) (Smith-Kline Beecham, Harlow, UK); the 5-HT 3 receptor antagonist MDL 72222 (3-tropanyl-3,5-dichlorobenzoate); the NMDA receptor antagonist ifenprodil (2-(4-benzylpiperidino)-1-(4-hydroxyphenyl)-1-propanol) (Research Biochemicals International, Natick, $\mathrm{MA}$ ); the nonpeptide CRF antagonist CRA1000 $\bullet \mathrm{H}_{2} \mathrm{SO}_{4}$ (2-[N-(2-methylthio-4isopropylphenyl)-N-ethylamino]-4-[4-(3-fluorophenyl)-1,2,3,6-tetrahydropyridin-1-yl]-6methylpyrimidine) (Taisho Pharmaceutical Co., Ltd., Omiya, Japan); the benzodiazepine receptor antagonist flumazenil (RO15-1788, Hoffman-La Roche Inc., Nutley, NJ); and the benzodiazepine type 1 receptor agonist zolpidem (Synthelabo Recherche, Cedex, France). SB242084 (1 mg/kg), flumazenil (5 mg/kg), CRA1000 (1 mg/kg), and MDL $72222(1 \mathrm{mg} / \mathrm{kg})$ were prepared as fine suspensions after sonication in a $0.5 \%$ solution of carboxymethylcellulose (CMC), whereas ifenprodil $(5 \mathrm{mg} / \mathrm{kg}$ ) was prepared in distilled water. Zolpidem $(3 \mathrm{mg} / \mathrm{kg}$ ) was dissolved in saline. All drugs were administered as a 2-ml $/ \mathrm{kg}$ dose between 5 and $6 \mathrm{~h}$ into withdrawal and $7 \mathrm{~min}$ (flumazenil), $15 \mathrm{~min}$ (zolpidem), or $30 \mathrm{~min}$ (CRA1000, SB242084, ifenprodil, and MDL 72222) before behavioral testing. All doses of drugs were carefully chosen on the basis of evidence of anxiolytic activity in other models or on the basis of information documenting the highest doses that one could expect would limit sedative or other generally disruptive effects on rat behavior (Criswell \& Breese, 1993; Ebert et al., 1997; Harro et al., 2001; Mazzola-Pomietto et al., 1995; Millan et al., 2001; Moy et al., 
1997, 1998). To confirm drug effects and dose responsivity, these doses were tested in a replication experiment with additional doses as follows: ifenprodil, $2.5,5.0$, and $10.0 \mathrm{mg} / \mathrm{kg}$; zolpidem, 1.5 and $3.0 \mathrm{mg} / \mathrm{kg}$; MDL 72222, 0.3, 1.0, and $3.0 \mathrm{mg} / \mathrm{kg}$; flumazenil, 1.25, 2.50, and $5.00 \mathrm{mg} / \mathrm{kg}$; CRA1000, 0.25, 0.50, and $1.00 \mathrm{mg} / \mathrm{kg}$; SB242084, 0.25, 0.50, and $1.00 \mathrm{mg} /$ $\mathrm{kg}$. To determine the potential effects of these drugs in non-ethanol-treated rats, select doses of drugs were examined as follows in a final experiment: SB242084, $1 \mathrm{mg} / \mathrm{kg}$; CRA1000, 1 $\mathrm{mg} / \mathrm{kg}$; flumazenil, $5 \mathrm{mg} / \mathrm{kg}$; and ifenprodil, $5 \mathrm{mg} / \mathrm{kg}$.

\subsection{Behavioral testing}

The primary behavioral test of anxiety used was the social interaction test (Duxon et al., 1997; File et al., 1996, 1999; File \& Hyde, 1977; Gonzalez et al., 1996). Between 5 and 6 h into withdrawal, two identically treated pairs of rats, naive to the test and approximately equal in body weight, were placed into the center of a test box $(\mathrm{a} 60 \times 60-\mathrm{cm}$ square open field with $1615 \times 15$-cm squares marked on the floor) simultaneously for a 5 -min period. The time each rat engaged in social interaction (conspecific grooming, sniffing, following, crawling over/ under) with its partner was recorded by an observer blind to the treatment conditions. Increased anxiety was inferred from reduced social interaction times. Locomotor activity, recorded as the number of squares entered during the 5-min session, was also recorded. It is important to emphasize that, unlike the plus-maze test behavior, all behavioral subcomponents of social interaction except "following" are independent of forward locomotion. Thus, when social interaction is present the animals tend to stay within the same square or two. Then, when a bout of interaction ends animals may or may not ambulate from square to square. Furthermore, results of other recent work in this laboratory have established that social interaction behavior within rat pairs was not correlated (Overstreet et al., 2002), a finding that reflects the fact that one animal may be actively engaged in a particular behavior such as grooming while the other is not. On the basis of these observations, as well as analyses with the use of individual animal data or data representing the combined data from the pair give comparable results (Overstreet et al., 2003), scores from individual rats were used in all analyses.

A second behavioral test of anxiety, the elevated plus-maze, was used in a subgroup of rats immediately before the social interaction test (Moy et al., 1997; Pellow et al., 1985). Rats were placed in the maze for $5 \mathrm{~min}$ and scored for the number of entries into and time spent in the open arms of the maze. Locomotor activity in the maze was determined from the number of closed-arm entries (File et al., 1999; Pellow et al., 1985), whereas the measure of anxiety-like behavior was inferred from diminished time in the open arms (Gonzalez et al., 1998).

\subsection{Statistical analysis}

Social interaction time in seconds and the number of squares entered are normally distributed scores. Therefore, data were analyzed by analysis of variance (ANOVA). A similar strategy was used for plus-maze test data, on which analyses were conducted of the closed-arm entries and the time in open arms. When significant, Tukey tests were used to compare pairs of groups $(n=8-10)$.

\section{Results}

\subsection{Experiment 1: effect of ethanol withdrawal on social interaction and locomotor activity}

Rats experiencing ethanol withdrawal consistently reduced their time in social interaction across all experiments in the current study. Normally, rats engaged in 30 to $40 \mathrm{~s}$ of social interaction during the 5-min test period (Fig. 1), whereas ethanol-withdrawn rats typically displayed only 5 to $10 \mathrm{~s}$ of this behavior $[t(18)=6.19, P<.001]$. Ethanol withdrawal also reduced locomotor activity (Fig. 1), as reflected in lower numbers of squares entered during the social interaction test $[t(18)=3.22, P<.01]$. However, the reduction in social interaction 
was not simply a consequence of the decreased locomotor activity, because the groups were still different when the scores for social interaction and locomotor activity were compared as a ratio. Rats that received control diet had a ratio of 0.32 , whereas those exposed to the ethanol diet had ratios of only 0.18 (indicating that the withdrawal preferentially affected the social interaction measure). A different profile of drug action emerged for effects on locomotor activity.

\subsection{Experiment 2: effect of flumazenil, SB242084, and ifenprodil on social interaction, locomotor activity, and plus-maze test behavior}

The initial series of pharmacological manipulations comparing results with the social interaction test revealed specific receptor-dependent and behavior-dependent effects during ethanol withdrawal. Among the group differences in the social interaction test $[F(4,36)=10.29$, $P<.0001]$, the benzodiazepine antagonist flumazenil and the 5- $\mathrm{HT}_{2 \mathrm{C}}$ receptor antagonist SB242084 attenuated ethanol withdrawal-induced deficits in social interaction time $(P<.05$ vs. vehicle; Fig. 2). This effect was also observed when ratios of social interaction to locomotor activity were compared (data not shown). In contrast, the NMDA receptor antagonist ifenprodil exerted a limited effect in the social interaction test (Fig. 2; $P>.05$ vs. vehicle). In the social interaction test, a significant group effect on the locomotor activity measure was found [Fig. $2 ; F(4,36)=5.05, P<.005]$. Drug effects on social interaction were not accompanied by reduction of activity deficits. The pattern of results in the plus-maze test experiment mirrored the social interaction results (Fig. 3). For example, significant differences were found in openarm time $[F(4,31)=5.31, P<.005]$ and closed-arm entries $[F(4,31)=7.49, P<.001]$ among treatment groups. Ethanol withdrawal reduced the number of closed-arm entries and the amount of time that the rats spent in the open arms by $57 \%$ and $76 \%$, respectively (Fig. 3). Flumazenil and SB242084 were active in the test, but ifenprodil was not.

\subsection{Experiment 3: effects of MDL 72222, CRA1000, and ifenprodil on social interaction and locomotor activity}

Given the parallel pharmacological profiles of behavioral activity in the social interaction test and the plus-maze test, other agents were examined only in the social interaction test. Among the group differences seen during withdrawal $[F(4,33)=18.93, P<.0001]$, the $\mathrm{CRF}_{1}$ receptor antagonist CRA1000 attenuated social interaction deficits $(P<.05$ vs. vehicle; Fig. 4$)$. The 5$\mathrm{HT}_{3}$ receptor antagonist MDL 72222 did not attenuate social interaction deficits $(P>.05$ vs. vehicle; Fig. 4). In the social interaction test, a significant group effect on the locomotor activity measure was found [Fig. $4 ; F(4,33)=10.99, P<.0001]$. Drug effects on social interaction were not accompanied by reduction of activity deficits.

\subsection{Experiment 4: effect of flumazenil, zolpidem, and ifenprodil on social interaction and locomotor activity}

The ameliorative effects of flumazenil on social interaction deficits were again revealed $(P<$. 05 vs. vehicle) among the group effects $[F(4,34)=11.85, P<.0001]$ in Experiment 4 (Fig. 5). The benzodiazepine type 1 receptor agonist zolpidem did not attenuate social interaction deficits in this experiment $(P>.05$ vs. vehicle; Fig. 5). In the social interaction test, a significant group effect on the locomotor activity measure was found [Fig. 5; $F(4,34)=5.43, P<.005$ ]. Drug effects on social interaction were not accompanied by reduction of activity deficits.

\subsection{Effect of study drugs in control rats not exposed to ethanol}

In control rats that had not been exposed to ethanol, no significant effect of the drugs on social interaction behavior was observed, with the exception of ifenprodil, which reduced social interaction behavior (Table 1). Ifenprodil and flumazenil significantly attenuated locomotor behavior in control rats, but CRA1000 and SB242084 did not (Table 1). 


\subsection{Evaluation of multiple drug doses}

In corroboration of the single-dose study results, MDL 72222 and zolpidem were also not active at any dose when evaluated in multiple-dose experiments (Table 2) and were not pursued further. The lack of effect of ifenprodil in the social interaction test was replicated at three different doses (Table 2). Flumazenil, CRA1000, and SB242084 reversed withdrawal-induced deficits in social interaction time, as in the single-dose experiments (Table 2). The most robust effects were observed at the highest doses of these drugs.

\section{Discussion}

The replicated results from experiments in the current study demonstrate that a model incorporating relatively short-term (17 days) dietary ethanol intake and the social interaction test can be used to study anxiety-like behavior during ethanol withdrawal in rats. These results also demonstrate that pharmacological blockade of 5- $\mathrm{HT}_{2 \mathrm{C}}, \mathrm{CRF}_{1}$, or benzodiazepine receptors, but not blockade of $5-\mathrm{HT}_{3}$ or stimulation of specific benzodiazepine type 1 receptors, during withdrawal from ethanol can attenuate anxiety-like responding in the relative absence of drug effects on withdrawal-induced suppression of general locomotor activity. The independence of locomotor activity from anxiety-like responding observed in the experiments in the current study supports previous findings in this model [Breese et al. (online publication 10 July 2003 at http://www.acnp.org/citations/Npp07100303159/default.pdf); Overstreet et al. $(2002,2003)]$. Thus, anxiety-like behavior can be manipulated in a sign-specific manner in the social interaction test. These results emphasize the importance of breaking down the withdrawal syndrome into its respective signs for study and intervention. The findings should promote efforts to develop pharmacotherapies for specific ethanol withdrawal signs that otherwise may independently promote further cycles of intake and withdrawal.

The role of benzodiazepine receptors in the expression of anxiety-like behavior during ethanol withdrawal was consistently shown in the results of previous experiments [see, for example, Criswell \& Breese (1993), File et al. (1992), Jung et al. (2000), and Moy et al. (1997, 2000)]. However, a general agonist action at benzodiazepine receptors may be insufficient to encompass the relevant mechanisms operating in the current experiments. For example, gamma-aminobutyric acid $\mathrm{B}\left(\mathrm{GABA}_{\mathrm{B}}\right)$ receptors may also be engaged at this time because baclofen antagonized ethanol withdrawal-induced deficits in behavior in social interaction and plus-maze tests (File et al., 1991, 1992). With regard to $\mathrm{GABA}_{\mathrm{A}}$ receptors, zolpidem preferentially binds to $\alpha_{1}$ GABA subunit-containing receptors (benzodiazepine type 1 receptors) (Doble, 1999; Mereu et al., 1990), an effect that may bias zolpidem's behavioral actions toward sedation rather than anxiolysis (McKernan et al., 2000). This action of zolpidem differs from that of the classic benzodiazepines, which are less specific. However, previous study findings from our laboratory showed that zolpidem possesses anxiolytic activity in the elevated plus-maze during withdrawal, and other study findings showed that zolpidem possesses this behavioral action in normal (control) animals as well [see, for example, Griebel et al. (1996) and Pellow and File (1986)]. Because the ethanol withdrawal-induced social interaction deficits were somewhat less severe in the first zolpidem experiment (i.e., $47 \%$ reduction), it is possible that the potential anxiolytic action of zolpidem might have been more apparent against a typical background of more severe deficits (70\%-90\% reductions).

However, in the replication experiment, the more typical withdrawal deficit was not blocked by either of two doses tested. Thus, that zolpidem is apparently not clinically useful in human beings for anxiety, is sedative at higher doses, and is not active against social interaction deficits during ethanol withdrawal underscore the potential importance of the actions of flumazenil and benzodiazepine type 2 agents in the anxiety associated with alcoholism.

Because the anxiolytic action of benzodiazepines in both control and withdrawn animals is most likely related to their ability to enhance GABA function in key brain regions, one might 
predict that the benzodiazepine antagonist flumazenil would have no effect on, or perhaps would exacerbate, anxiety-like behavior during withdrawal. However, in the current study and other studies [see, for example, Criswell \& Breese (1993), File et al. $(1989,1992)$, and Moy et al. $(1997,2000)$ ], flumazenil blocked anxiety-like behavior in different tests involving different withdrawal paradigms. These findings argue for a second mechanism of action, perhaps related to the blockade of endogenous benzodiazepine inverse agonists that may be present at the benzodiazepine receptor at this time (Buck et al., 1991; File et al., 1989; Moy et al., 1997, 2000). This effect is interesting in light of the fact that flumazenil has a half-life of 16 min (Lister et al., 1984) and yet can reduce anxiety-like behavior of ethanol withdrawal when administered many hours or days before a single withdrawal (Buck et al., 1991; File et al., 1989) or during multiple withdrawals before a final withdrawal (Knapp et al., 2001). This persistent effect of flumazenil in the absence of drug underscores the possibility that an important and persistent ethanol-dependent phenomenon is at work that may relate to specific interactions with the rich structural and functional diversity of GABA and benzodiazepine receptors. The inactivity of zolpidem in the current experiments also supports the suggestion of involvement of non-type 1 benzodiazepine receptors in this flumazenil effect, which was most marked at higher doses. It is known that various binding sites have differential affinities for and responses to flumazenil (Barnard et al., 1998), and potential structural adaptations of GABA receptors in select cells or brain regions after chronic ethanol treatment [see, for example, Grobin et al. (2000), Papadeas et al. (2001), and Petrie et al. (2001)] may mediate these differences. Furthermore, results of the dose-ranging and drug-treated control experiments demonstrate that the antianxiety actions during withdrawal can occur without correcting locomotor deficits in the plus-maze or social interaction test or without having actions on anxiety in control animals. One can propose, then, that flumazenil and the endogenous inverse agonists that it may block [e.g., octadecaneuropeptide (ODN), diazepam binding inhibitor (DBI), or triakontatetraneuropeptide (TTN)] compete for unique receptor sites differentially in chronic ethanol-treated versus control states. This proposition may be particularly important if it can be shown that these endogenous benzodiazepines have preferential actions on benzodiazepine type 2 receptors.

The potential role of 5-HT in ethanol withdrawal-associated anxiety was supported in previous reports (Gatch et al., 2000; Lal et al., 1993; Overstreet et al., 2000; Prather et al., 1991; To et al., 1999). Results of experiments in the current study extend previous research findings by showing an impressive ability of the selective 5- $\mathrm{HT}_{2 \mathrm{C}}$ receptor antagonist SB242084 to ameliorate deficits in social interaction and plus-maze open-arm time induced by ethanol withdrawal. Moreover, the drug was without significant effect on either locomotor activity or social interaction in control rats. In the plus-maze test, reduced locomotor activity (reduced closed-arm entries) arguably complicates the selectivity of the test for anxiety-like behavior during withdrawal. However, that both SB242084 and flumazenil were shown to increase the time in open arms despite the ethanol-induced reduction in closed-arm entries supports the suggestion that the anxiety-like behavior is to a significant extent independent of the locomotor activity. In other studies, lower doses of the $5-\mathrm{HT}_{2 \mathrm{C}}$ receptor agonist $\mathrm{m}$-chlorophenylpiperazine (mCPP) were required to induce a maximum anxiogeniclike response in ethanol-withdrawn rats relative to control rats (Rezazadeh et al., 1993). Together, these results seem to indicate that 5-HT $2 \mathrm{C}$ receptors, perhaps in the amygdala [see Pompeiano et al. (1994)], may play an important role in the expression of the anxiety-like signs of ethanol withdrawal. These results are also consistent with the proposed role for $5-\mathrm{HT}_{2 \mathrm{~A} / 2 \mathrm{C}}$ receptor-mediated protein kinase $\mathrm{C}$ (PKC)/phosphoinositide (PI) signaling in ethanol dependence (Pandey, 1998; Pandey \& Pandey, 1996).

The failure of the $5-\mathrm{HT}_{3}$ receptor antagonist MDL 72222 to block social interaction deficits supports the suggestion that these receptors are not involved significantly in the expression of anxiety-like behavior during ethanol withdrawal. However, because this $5-\mathrm{HT}_{3}$ receptor 
antagonist blocked anxiety-like behavior in other contexts (Bilkei-Gorzó et al., 1998; Higgins et al., 1991) and chronic treatment with another $5-\mathrm{HT}_{3}$ antagonist, ondansetron, attenuated social interaction deficits in ethanol-withdrawn rats (Costall et al., 1990), there seem to be specific complex actions of 5-HT at this receptor that as yet need to be resolved. One could argue that the anxiolytic dose range of this drug may not include the dose used in the current study. However, evidence seems to indicate that higher doses can be sedative (MazzolaPomietto et al., 1995). Therefore, it is unlikely that MDL 72222 could reverse social interaction deficits in this model. Overall, these observations of SB242084 and MDL 72222 seem to indicate that the action of 5-HT during ethanol withdrawal on anxiety-like behavior may depend on the 5-HT receptor subtype and the subtype of anxiety-like behavior assessed in different tests.

Overactivity of the CRF system in anxiety occurring during ethanol withdrawal, as well as in non-ethanol-treated animals, has been implicated in a number of studies. Alcohol or a peptide CRF antagonist attenuates CRF-induced or withdrawal-induced anxiety-like behavior (Baldwin et al., 1991; Thatcher-Britton \& Koob, 1986). Results of similar studies support the suggestion that amygdala CRF may play an important role in this effect (Menzaghi et al., 1994; Merlo Pich et al., 1995; Rassnick et al., 1993). Results of the current studies are consistent with those findings, in that the novel selective nonpeptide $\mathrm{CRF}_{1}$ receptor antagonist CRA1000 (Chaki et al., 1999; Okuyama et al., 1999) dose-dependently blocked the expression of social interaction deficits in withdrawing animals. This effect seemed to be specific for anxiety-like behavior in withdrawing animals, because there were no significant effects on locomotor deficits in withdrawing rats or normal locomotor or social interaction behaviors in control rats.

Because the NMDA receptor antagonist ifenprodil was not active in ethanol-withdrawn rats in the current study at any dose, it would appear that NMDA receptors are not exerting significant effects on anxiety-like behavior during ethanol withdrawal. Ifenprodil was not active in either the plus-maze or social interaction test, despite being used at or above a dose that is behaviorally active against the diazepam withdrawal syndrome and hypoxia (Eraković et al., 1997; Tsuda et al., 1998). This observation, combined with the anxiogenic-like response seen in control rats, supports the suggestion that the drug is not likely to be a good anxiolytic prospect in alcoholism. The drug also inhibited locomotor activity in control rats, but no differential effect was seen in withdrawing rats treated with ifenprodil or vehicle. These results are important in determining receptor targets relevant to expression of withdrawal signs because evidence consistently shows that NMDA receptors play a role in action of glutamate receptor-mediated hyperexcitability during withdrawal (Kumari \& Ticku, 2000). In other studies, the competitive NMDA receptor antagonists 2-amino-7-phosphonoheptanoic acid (AP-7) and D.,- $(E)$-amino-4methyl-5-phosphono-3-pentenoic acid (CGP 37849), but not the noncompetitive NMDA receptor channel blocker MK-801, attenuated the plus-maze deficits during ethanol withdrawal in the elevated plus-maze (Criswell et al., 1994; Gatch et al., 1999). These results support the suggestion that glutamate action on this behavior during ethanol withdrawal depends on the receptor subtype and the mechanism of receptor blockade.

In summary, results of experiments in the current study revealed anxiety-like behavior during withdrawal from short-term ethanol intake that was attenuated by antagonists of

benzodiazepine, $\mathrm{CRF}$, and 5- $\mathrm{HT}_{2 \mathrm{C}}$ receptors, but not by antagonists of NMDA-type glutamate or 5- $\mathrm{HT}_{3}$ receptors or an agonist of benzodiazepine type 1 receptors. These results support the suggestion that multiple neuronal systems may contribute to the specific ethanol withdrawal sign of anxiety and that anxiety can be manipulated in a pharmacologically selective manner. These results are consistent with the general theoretical principle that negative reinforcement (e.g., tension reduction, anxiety reduction, and alleviation of other signs and symptoms of acute or chronic ethanol withdrawal) is a potentially important motivator of pathologic levels of alcohol consumption (Cappell \& LeBlanc, 1981; Hershon, 1977; Koob \& Le Moal, 1997). 


\section{Acknowledgments}

We thank Lee Gause for assistance with preparing and administering the ethanol diets. This work was supported by National Institute on Alcohol Abuse and Alcoholism grants AA00214 (D.J.K.) and AA11605/AA10025/AA00253/ AA12655 (G.R.B.).

\section{References}

Andrews N, File SE, Fernandes C, Gonzalez LE, Barnes NM. Evidence that the median raphe nucleusdorsal hippocampal pathway mediates diazepam withdrawal-induced anxiety. Psychopharmacology (Berl) 1997;130:228-234. [PubMed: 9151356]

Baldwin HA, Rassnick S, Rivier J, Koob GF, Britton KT. CRF antagonist reverses the "anxiogenic" response to ethanol withdrawal in the rat. Psychopharmacology (Berl) 1991;103:227-232. [PubMed: 2027923]

Barnard EA, Skolnick P, Olsen RW, Mohler H, Sieghart W, Biggio G, Braestrup C, Bateson AN, Langer SZ. International Union of Pharmacology. XV. Subtypes of $\gamma$-aminobutyric acid receptors: $^{-}$ classification on the basis of subunit structure and receptor function. Pharmacol Rev 1998;50:291313. [PubMed: 9647870]

Bilkei-Gorzó A, Gyertyán I, Lévay G. mCPP-induced anxiety in the light-dark box in rats—a new method for screening anxiolytic activity. Psychopharmacology (Berl) 1998;136:291-298. [PubMed: 9566815]

Breese GR, Knapp DJ, Overstreet DH. Stress sensitization of ethanol withdrawal-induced reduction in social interaction: inhibition by CRF-1 and benzodiazepine receptor antagonists and a $5-\mathrm{HT}_{1 \mathrm{~A}^{-}}$ receptor agonist. (Online Publication: 10 July 2003), At http://www.acnp.org/citations/ Npp07100303159/default.pdf. (Source of work cited in this article is online publication of 10 July 2003, previously noted pdf file. For reader information: subsequent advance online publication, 03 September 2003, doi:10.1038/sj.npp.1300282; print publication, Neuropsychopharmacology 29, 470482).

Buck KJ, Heim H, Harris RA. Reversal of alcohol dependence and tolerance by a single administration of flumazenil. J Pharmacol Exp Ther 1991;257:984-989. [PubMed: 1646333]

Cappell, H.; LeBlanc, AE. Tolerance and physical dependence: do they play a role in alcohol and drug self-administration?. In: Israel, Y.; Glaser, FB.; Kalant, H.; Popham, RE.; Schmidt, W.; Smart, RG., editors. Research Advances in Alcohol and Drug Problems. Vol. vol. 6. New York: Plenum Press; 1981. p. 159-196.

Chaki S, Okuyama S, Nakazato A, Kumagai T, Okubo T, Ikeda Y, Oshida Y, Hamajima Y, Tomisawa $\mathrm{K}$. In vitro pharmacological profile of nonpeptide $\mathrm{CRF}_{1}$ receptor antagonists, CRA1000 and CRA1001. Eur J Pharmacol 1999;371:205-211. [PubMed: 10357258]

Costall B, Domeney AM, Gerrard PA, Kelly ME, Naylor RJ. Zacopride: anxiolytic profile in rodent and primate models of anxiety. J Pharm Pharmacol 1988;40:302-305. [PubMed: 2900320]

Costall B, Jones BJ, Kelly ME, Naylor RJ, Onaivi ES, Tyers MB. Ondansetron inhibits a behavioural consequence of withdrawing from drugs of abuse. Pharmacol Biochem Behav 1990;36:339-344. [PubMed: 2141423]

Criswell HE, Breese GR. Similar effects of ethanol and flumazenil on acquisition of a shuttle-box avoidance response during withdrawal from chronic ethanol treatment. Br J Pharmacol 1993;110:753-760. [PubMed: 8242248]

Criswell HE, Knapp DJ, Overstreet DH, Breese GR. Effects of ethanol, chlordiazepoxide, and MK-801 on performance in the elevated-plus maze and on locomotor activity. Alcohol Clin Exp Res 1994;18:596-601. [PubMed: 7943661]

Doble A. New insights into the mechanism of action of hypnotics. J Psychopharmacol 1999;13:S11-S20. [PubMed: 10667451]

Dunn RW, Corbett R, Fielding S. Effects of 5- $\mathrm{HT}_{1 \mathrm{~A}}$ receptor agonists and NMDA receptor antagonists in the social interaction test and the elevated plus maze. Eur J Pharmacol 1989;169:1-10. [PubMed: 2574684]

Duxon MS, Kennett GA, Lightowler S, Blackburn TP, Fone KCF. Activation of 5-HT 2 B receptors in the medial amygdale causes anxiolysis in the social interaction test in the rat. Neuropharmacology 1997;36:601-608. [PubMed: 9225285] 
Ebert U, Wlaź P, Löscher W. Anticonvulsant effects by combined treatment with a glycineB receptor antagonist and a polyamine site antagonist in amygdala-kindled rats. Eur J Pharmacol 1997;322:179_ 184. [PubMed: 9098685]

Eraković V, Župan G, Mršić J, Simonić A, Varljen J. The influence of nicardipine and ifenprodil on the brain free arachidonic acid level and behavior in hypoxia-exposed rats. Prog Neuropsychopharmacol Biol Psychiatry 1997;21:633-647. [PubMed: 9194145]

File SE. Anxiolytic action of a neurokinin ${ }_{1}$ receptor antagonist in the social interaction test. Pharmacol Biochem Behav 1997;58:747-752. [PubMed: 9329068]

File SE, Andrews N, al-Farhan M. Anxiogenic responses of rats on withdrawal from chronic ethanol treatment: effects of tianeptine. Alcohol Alcohol 1993a;28:281-286. [PubMed: 8352839]

File SE, Andrews N, al-Farhan M, Wu PY. The role of 5-HT in the anxiogenic effects of acute ethanol withdrawal and in the long-lasting cognitive deficits. Alcohol Alcohol Suppl 1993b;2:495-499. [PubMed: 7748345]

File SE, Baldwin HA, Hitchcott PK. Flumazenil but not nitrendipine reverses the increased anxiety during ethanol withdrawal in the rat. Psychopharmacology (Berl) 1989;98:262-264. [PubMed: 2502796]

File SE, Gonzalez LE, Andrews N. Comparative study of pre- and postsynaptic 5- $\mathrm{HT}_{1 \mathrm{~A}}$ receptor modulation of anxiety in two ethological animal tests. J Neurosci 1996;16:4810-4815. [PubMed: 8764667]

File SE, Hyde JR. The effects of p-chlorophenylalanine and ethanolamine-O-sulphate in an animal test of anxiety. J Pharm Pharmacol 1977;29:735-738. [PubMed: 22619]

File SE, Ouagazzal AM, Gonzalez LE, Overstreet DH. Chronic fluoxetine in tests of anxiety in rat lines selectively bred for differential 5-HT 1 A receptor function. Pharmacol Biochem Behav 1999;62:695701. [PubMed: 10208375]

File SE, Zharkovsky A, Gulati K. Effects of baclofen and nitrendipine on ethanol withdrawal responses in the rat. Neuropharmacology 1991;30:183-190. [PubMed: 2030822]

File SE, Zharkovsky A, Hitchcott PK. Effects of nitrendipine, chlordiazepoxide, flumazenil and baclofen on the increased anxiety resulting from alcohol withdrawal. Prog Neuropsychopharmacol Biol Psychiatry 1992;16:87-93. [PubMed: 1557510]

Frye GD, Chapin RE, Vogel RA, Mailman RB, Kilts CD, Mueller RA, Breese GR. Effects of acute and chronic 1,3-butanedione treatment on central nervous system function: a comparison with ethanol. J Pharmacol Exp Ther 1981;216:306-314. [PubMed: 7193248]

Gatch MB, Wallis CJ, Lal H. Effects of NMDA antagonists on ethanol-withdrawal induced "anxiety" in the elevated plus maze. Alcohol 1999;19:207-211. [PubMed: 10580509]

Gatch MB, Wallis CJ, Lal H. Effects of ritanserin on ethanol withdrawal-induced anxiety in rats. Alcohol 2000;21:11-17. [PubMed: 10946153]

Gonzalez LE, Andrews N, File SE. 5-HT $1 \mathrm{~A}$ and benzodiazepine receptors in the basolateral amygdala modulate anxiety in the social interaction test, but not in the elevated plus-maze. Brain Res 1996;732:145-153. [PubMed: 8891278]

Gonzalez LE, File SE, Overstreet DH. Selectively bred lines of rats differ in social interaction and hippocampal 5-HT $1 \mathrm{~A}$ receptor function: a link between anxiety and depression? Pharmacol Biochem Behav 1998;59:787-792. [PubMed: 9586832]

Griebel G, Perrault G, Sanger DJ. A comparative study of the effects of selective and non-selective 5$\mathrm{HT}_{2}$ receptor subtype antagonists in rat and mouse models of anxiety. Neuropharmacology 1997;36:793-802. [PubMed: 9225307]

Griebel G, Sanger DJ, Perrault G. The use of the rat elevated plus-maze to discriminate between nonselective and BZ-1 ( $\omega 1)$ selective, benzodiazepine receptor ligands. Psychopharmacology (Berl) 1996;124:245-254. [PubMed: 8740046]

Grobin AC, Fritschy JM, Morrow AL. Chronic ethanol administration alters immunoreactivity for $\mathrm{GABA}_{\mathrm{A}}$ receptor subunits in rat cortex in a region-specific manner. Alcohol Clin Exp Res 2000;24:1137-1144. [PubMed: 10968650]

Harro J, Tõnissaar M, Eller M. The effects of CRA 1000, a non-peptide antagonist of corticotropinreleasing factor receptor type 1, on adaptive behaviour in the rat. Neuropeptides 2001;35:100-109. [PubMed: 11384205] 
Hershon HI. Alcohol withdrawal symptoms and drinking behavior. J Stud Alcohol 1977;38:953-971. [PubMed: 881849]

Higgins GA, Jones BJ, Oakley NR, Tyers MB. Evidence that the amygdala is involved in the disinhibitory effects of 5-HT 3 receptor antagonists. Psychopharmacology (Berl) 1991;104:545-551. [PubMed: 1664112]

Horváth ZC, Czopf J, Buzsáki G. MK-801-induced neuronal damage in rats. Brain Res 1997;753:181195. [PubMed: 9125402]

Institute of Laboratory Animal Resources, Commission on Life Sciences, National Research Council. Washington, DC: National Academy Press; 1996. Guide for the Care and Use of Laboratory Animals. URL: http://oacu.od.nih.gov/regs/guide/guidex.htm

June HL, Eggers MW, Warren-Reese C, DeLong J, Ricks-Cord A, Durr LF, Cason CR. The effects of the novel benzodiazepine receptor inverse agonist $\mathrm{Ru} 34000$ on ethanol-maintained behaviors. Eur J Pharmacol 1998a;350:151-158. [PubMed: 9696402]

June HL, Torres L, Cason CR, Hwang BH, Braun MR, Murphy JM. The novel benzodiazepine inverse agonist RO19-4603 antagonizes ethanol motivated behaviors: neuropharmacological studies. Brain Res 1998b;784:256-275. [PubMed: 9518641]

Jung ME, Wallis CJ, Gatch MB, Lal H. Abecarnil and alprazolam reverse anxiety-like behaviors induced by ethanol withdrawal. Alcohol 2000;21:161-168. [PubMed: 10963939]

Kampov-Polevoy AB, Matthews DB, Gause L, Morrow AL, Overstreet DH. P rats develop physical dependence on alcohol via voluntary drinking: changes in seizure thresholds, anxiety, and patterns of alcohol drinking. Alcohol Clin Exp Res 2000;24:278-284. [PubMed: 10776663]

Kennett GA, Wood MD, Bright F, Cilia J, Piper DC, Gager T, Thomas D, Baxter GS, Forbes IT, Ham $\mathrm{P}$, Blackburn TP. In vitro and in vivo profile of SB 206553, a potent $5-\mathrm{HT}_{2} \mathrm{C} / 5-\mathrm{HT}_{2 \mathrm{~B}}$ receptor antagonist with anxiolytic-like properties. Br J Pharmacol 1996;117:427-434. [PubMed: 8821530]

Kennett GA, Wood MD, Bright F, Trail B, Riley G, Holland V, Avenell KY, Stean T, Upton N, Bromidge S, Forbes IT, Brown AM, Middlemiss DN, Blackburn TP. SB 242084, a selective and brain penetrant 5-HT 2 C receptor antagonist. Neuropharmacology 1997;36:609-620. [PubMed: 9225286]

Knapp DJ, Duncan GE, Crews FT, Breese GR. Induction of Fos-like proteins and ultrasonic vocalizations during ethanol withdrawal: further evidence for withdrawal-induced anxiety. Alcohol Clin Exp Res 1998;22:481-493. [PubMed: 9581657]

Knapp DJ, Overstreet DH, Breese GR. Persistent effects of repeated ethanol withdrawal are blunted by pharmacological treatments during early withdrawal episodes. Alcohol Clin Exp Res 2001;25:23A. (Abstract).

Koob GF, Le Moal M. Drug abuse: hedonic homeostatic dysregulation. Science 1997;278:52-58. [PubMed: 9311926]

Kumari M, Ticku MK. Regulation of NMDA receptors by ethanol. Prog Drug Res 2000;54:152-189. [PubMed: 10857388]

Lal H, Prather PL, Rezazadeh SM. Anxiogenic behavior in rats during acute and protracted ethanol withdrawal: reversal by buspirone. Alcohol 1991;8:467-471. [PubMed: 1781924]

Lal H, Prather PL, Rezazadeh SM. Potential role of $5 \mathrm{HT}_{1 \mathrm{C}}$ and/or $5 \mathrm{HT}_{2}$ receptors in the mianserininduced prevention of anxiogenic behaviors occurring during ethanol withdrawal. Alcohol Clin Exp Res 1993;17:411-417. [PubMed: 8488986]

Lister RG, Greenblatt DJ, Abernethy DR, File SE. Pharmacokinetic studies on Ro 15-1788, a benzodiazepine receptor ligand, in the brain of the rat. Brain Res 1984;290:183-186. [PubMed: 6419985]

Mazzola-Pomietto P, Aulakh CS, Murphy DL. Temperature, food intake, and locomotor activity effects of a 5- $\mathrm{HT}_{3}$ receptor agonist and two 5- $\mathrm{HT}_{3}$ receptor antagonists in rats. Psychopharmacology (Berl) 1995;121:488-493. [PubMed: 8619014]

McKernan RM, Rosahl TW, Reynolds DS, Sur C, Wafford KA, Atack JR, Farrar S, Myers J, Cook G, Ferris P, Garrett L, Bristow L, Marshall G, Macaulay A, Brown N, Howell O, Moore KW, Carling RW, Street LJ, Castro JL, Ragan CI, Dawson GR, Whiting PJ. Sedative but not anxiolytic properties

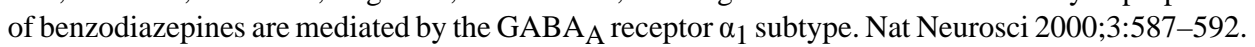
[PubMed: 10816315] 
Menzaghi F, Rassnick S, Heinrichs S, Baldwin H, Pich EM, Weiss F, Koob GF. The role of corticotropinreleasing factor in the anxiogenic effects of ethanol withdrawal. Ann N Y Acad Sci 1994;739:176184. [PubMed: 7832471]

Mereu G, Carcangiu G, Concas A, Passino N, Biggio G. Reduction of reticulata neuronal activity by zolpidem and alpidem, two imidazopyridines with high affinity for type I benzodiazepine receptors. Eur J Pharmacol 1990;179:339-345. [PubMed: 1973107]

Merlo Pich E, Lorang M, Yeganeh M, Rodriguez de Fonseca F, Raber J, Koob GF, Weiss F. Increase of extracellular corticotropin-releasing factor-like immunoreactivity levels in the amygdala of awake rats during restraint stress and ethanol withdrawal as measured by microdialysis. J Neurosci 1995;15:5439-5447. [PubMed: 7643193]

Meyer RE. Anxiolytics and the alcoholic patient. J Stud Alcohol 1986;47:269-273. [PubMed: 2875216]

Millan MJ, Brocco M, Gobert A, Dorey G, Casara P, Dekeyne A. Anxiolytic properties of the selective, non-peptidergic $\mathrm{CRF}_{1}$ antagonists, $\mathrm{CP} 154,526$ and DMP695: a comparison to other classes of anxiolytic agent. Neuropsychopharmacology 2001;25:585-600. [PubMed: 11557172]

Moy SS, Duncan GE, Knapp DJ, Breese GR. Sensitivity to ethanol across development in rats: comparison to [ $\left.{ }^{3} \mathrm{H}\right]$ zolpidem binding. Alcohol Clin Exp Res 1998;22:1485-1492. [PubMed: 9802533]

Moy SS, Knapp DJ, Criswell HE, Breese GR. Flumazenil blockade of anxiety following ethanol withdrawal in rats. Psychopharmacology (Berl) 1997;131:354-360. [PubMed: 9226737]

Moy SS, Knapp DJ, Duncan GE, Breese GR. Enhanced ultrasonic vocalization and Fos protein expression following ethanol withdrawal: effects of flumazenil. Psychopharmacology (Berl) 2000;152:208-215. [PubMed: 11057525]

Naranjo, CA.; Sellers, EM. Research Advances in New Psychopharmacological Treatments for Alcoholism. New York: Excerpta Medica; 1985.

Okuyama S, Chaki S, Kawashima N, Suzuki Y, Ogawa S, Nakazato A, Kumagai T, Okubo T, Tomisawa $\mathrm{K}$. Receptor binding, behavioral, and electrophysiological profiles of nonpeptide corticotropinreleasing factor subtype 1 receptor antagonists CRA1000 and CRA1001. J Pharmacol Exp Ther 1999;289:926-935. [PubMed: 10215672]

Overstreet, DH.; Knapp, DJ.; Breese, GR. Mechanisms involved in the acute anxiogenic effects of fluoxetine. Serotonin Club/Brain Research Bulletin conference, Serotonin: from Molecule to the Clinic; satellite to the Society for Neuroscience Meeting; November 2-3; New Orleans, USA. 2000. (Abstract)

Overstreet DH, Knapp DJ, Breese GR. Accentuated decrease in social interaction in rats subjected to repeated ethanol withdrawals. Alcohol Clin Exp Res 2002;26:1259-1268. [PubMed: 12198403]

Overstreet DH, Knapp DJ, Moy SS, Breese GR. A 5-HT 1 A agonist and a 5-HT 2 C antagonist reduce social interaction deficit induced by multiple ethanol withdrawals in rats. Psychopharmacology (Berl) 2003;167:344-352. [PubMed: 12677355]

Pandey SC. Neuronal signaling systems and ethanol dependence. Mol Neurobiol 1998;17:1-15. [PubMed: 9887443]

Pandey SC, Pandey GN. Modulation of serotonin $2 \mathrm{~A} / 2 \mathrm{C}$ receptors and these receptor-linked phosphoinositide system by ethanol. Behav Brain Res 1996;73:235-238. [PubMed: 8788509]

Papadeas S, Grobin AC, Morrow AL. Chronic ethanol consumption differentially alters GABA $\mathrm{A}_{\mathrm{A}}$ receptor $\alpha_{1}$ and $\alpha_{4}$ subunit peptide expression and $\mathrm{GABA}_{\mathrm{A}}$ receptor-mediated $36 \mathrm{Cl}^{-}$uptake in mesocorticolimbic regions of rat brain. Alcohol Clin Exp Res 2001;25:1270-1275. [PubMed: 11584145]

Pellow S, Chopin P, File SE, Briley M. Validation of open:closed arm entries in an elevated plus-maze as ameasure of anxiety in the rat. J Neurosci Methods 1985;14:149-167. [PubMed: 2864480]

Pellow S, File SE. Anxiolytic and anxiogenic drug effects on exploratory activity in an elevated plus maze: a novel test of anxiety in the rat. Pharmacol Biochem Behav 1986;24:525-529. [PubMed: 2871560]

Petrie J, Sapp DW, Tyndale RF, Park MK, Fanselow M, Olsen RW. Altered GABA A receptor subunit and splice variant expression in rats treated with chronic intermittent ethanol. Alcohol Clin Exp Res 2001;25:819-828. [PubMed: 11410716] 
Pompeiano M, Palacios JM, Mengod G. Distribution of the serotonin 5- $\mathrm{HT}_{2}$ receptor family mRNAs: comparison between 5- $\mathrm{HT}_{2 \mathrm{~A}}$ and 5-HT $2 \mathrm{C}$ receptors. Brain Res Mol Brain Res 1994;23:163-178. [PubMed: 8028479]

Prather PL, Rezazadeh SM, Lal H. Mianserin in the treatment of ethanol withdrawal in the rat: prevention of behaviors indicative of anxiety. Psychopharmacol Bull 1991;27:285-289. [PubMed: 1775600]

Rassnick S, Heinrichs SC, Britton KT, Koob GF. Microinjection of a corticotropin-releasing factor antagonist into the central nucleus of the amygdala reverses anxiogenic-like effects of ethanol withdrawal. Brain Res 1993;605:25-32. [PubMed: 8467387]

Rezazadeh SM, Prather PL, Lal H. Sensitization to $5-\mathrm{HT}_{1 \mathrm{C}}$ receptor agonist in rats observed following withdrawal from chronic ethanol. Alcohol 1993;10:281-283. [PubMed: 8397879]

Schaffer A, Naranjo CA. Recommended drug treatment strategies for the alcoholic patient. Drugs 1998;56:571-585. [PubMed: 9806104]

Snell LD, Claffey DJ, Ruth JA, Valenzuela CF, Cardoso R, Wang Z, Levinson SR, Sather WA, Williamson AV, Ingersoll NC, Ovchinnikova L, Bhave SV, Hoffman PL, Tabakoff B. Novel structure having antagonist actions at both the glycine site of the $N$-methyl-d-aspartate receptor and neuronal voltage-sensitive sodium channels: biochemical, electrophysiological, and behavioral characterization. J Pharmacol Exp Ther 2000;292:215-227. [PubMed: 10604951]

Thatcher-Britton K, Koob GF. Alcohol reverses the proconflict effect of corticotropin-releasing factor. Regul Pept 1986;16:315-320. [PubMed: 3031744]

To CT, Anheuer ZE, Bagdy G. Effects of acute and chronic fluoxetine treatment on CRH-induced anxiety. Neuroreport 1999;10:553-555. [PubMed: 10208588]

Tsuda M, Suzuki T, Misawa M. NMDA receptor antagonists potently suppress the spontaneous withdrawal signs induced by discontinuation of long-term diazepam treatment in Fischer 344 rats. Brain Res 1998;790:82-90. [PubMed: 9593834]

Wood MD, Reavill C, Trail B, Wilson A, Stean T, Kennett GA, Lightowler S, Blackburn TP, Thomas D, Gager TL, Riley G, Holland V, Bromidge SM, Forbes IT, Middlemiss DN. SB-243213; a selective $5-\mathrm{HT}_{2 \mathrm{C}}$ receptor inverse agonist with improved anxiolytic profile: lack of tolerance and withdrawal anxiety. Neuropharmacology 2001;41:186-199. [PubMed: 11489455]

Yang X, Criswell HE, Simson P, Moy S, Breese GR. Evidence for a selective effect of ethanol on $N$ methyl-d-aspartate responses: ethanol affects a subtype of the ifenprodil-sensitive $N$-methyl-daspartate receptors. J Pharmacol Exp Ther 1996;278:114-124. [PubMed: 8764342] 

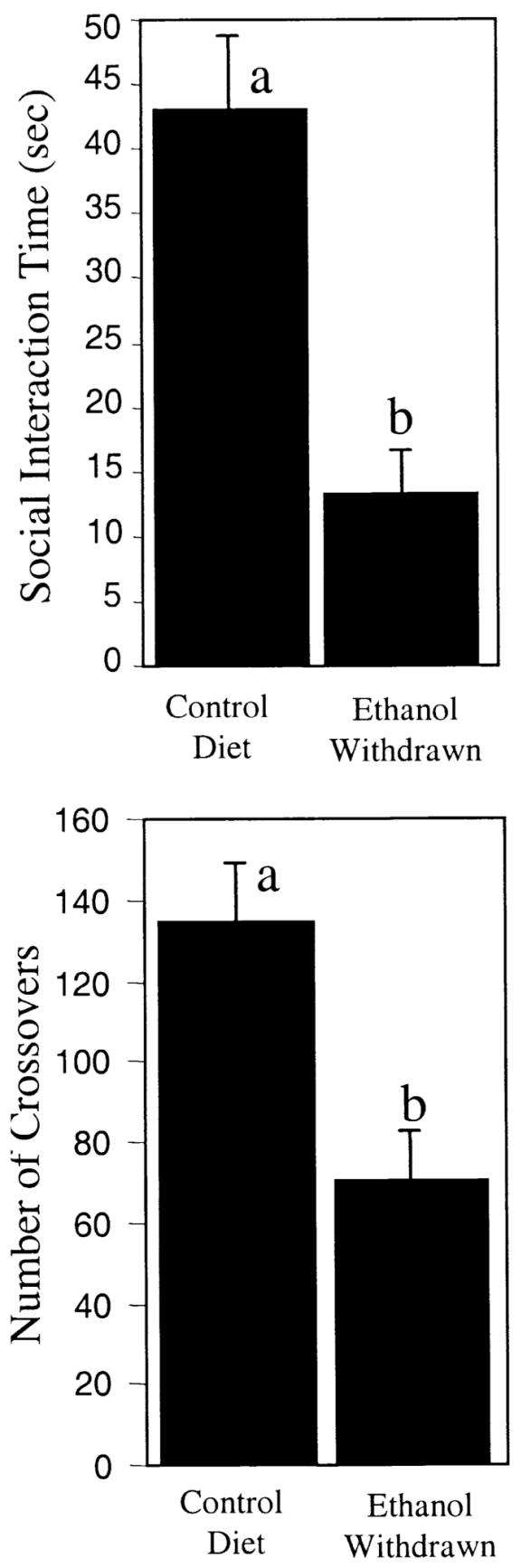

Fig. 1.

Mean social interaction time and locomotor activity scores for control and ethanol-withdrawn rats. For 17 days, rats were exposed to ethanol (8-12 g/kg/day), and their behavior was subsequently tested between 5 and $6 \mathrm{~h}$ into withdrawal. Bars (means \pm S.E.M.) that do not share common letters are significantly different from each other $(P<.05)$. 

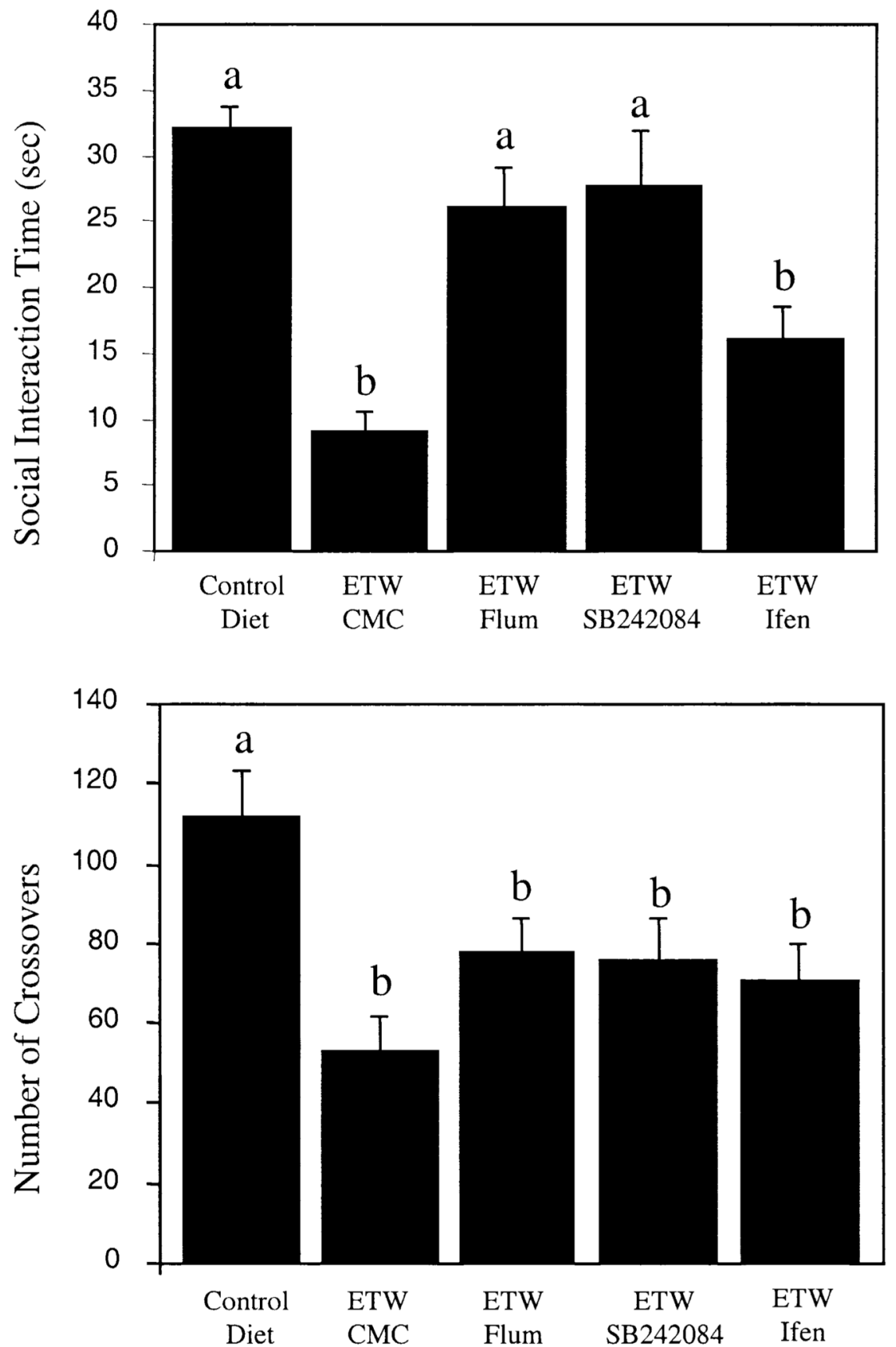

Fig. 2.

Mean social interaction time and locomotor activity scores for control and ethanol-withdrawn (ETW) rats treated with the 5-hydroxytryptamine (serotonin) $2 \mathrm{C}\left(5-\mathrm{HT}_{2} \mathrm{C}\right)$ receptor antagonist SB242084, the benzodiazepine receptor antagonist flumazenil (Flum), or the $N$-methyl-Daspartate (NMDA)-type glutamate receptor antagonist ifenprodil (Ifen). Rats were treated for 17 days with $7 \%$ (weight/volume) ethanol diet and tested between 5 and $6 \mathrm{~h}$ into withdrawal. Bars (means \pm S.E.M.) that do not share common letters are significantly different from each other $(P<.05)$. CMC $=0.5 \%$ solution of carboxymethylcellulose vehicle. 

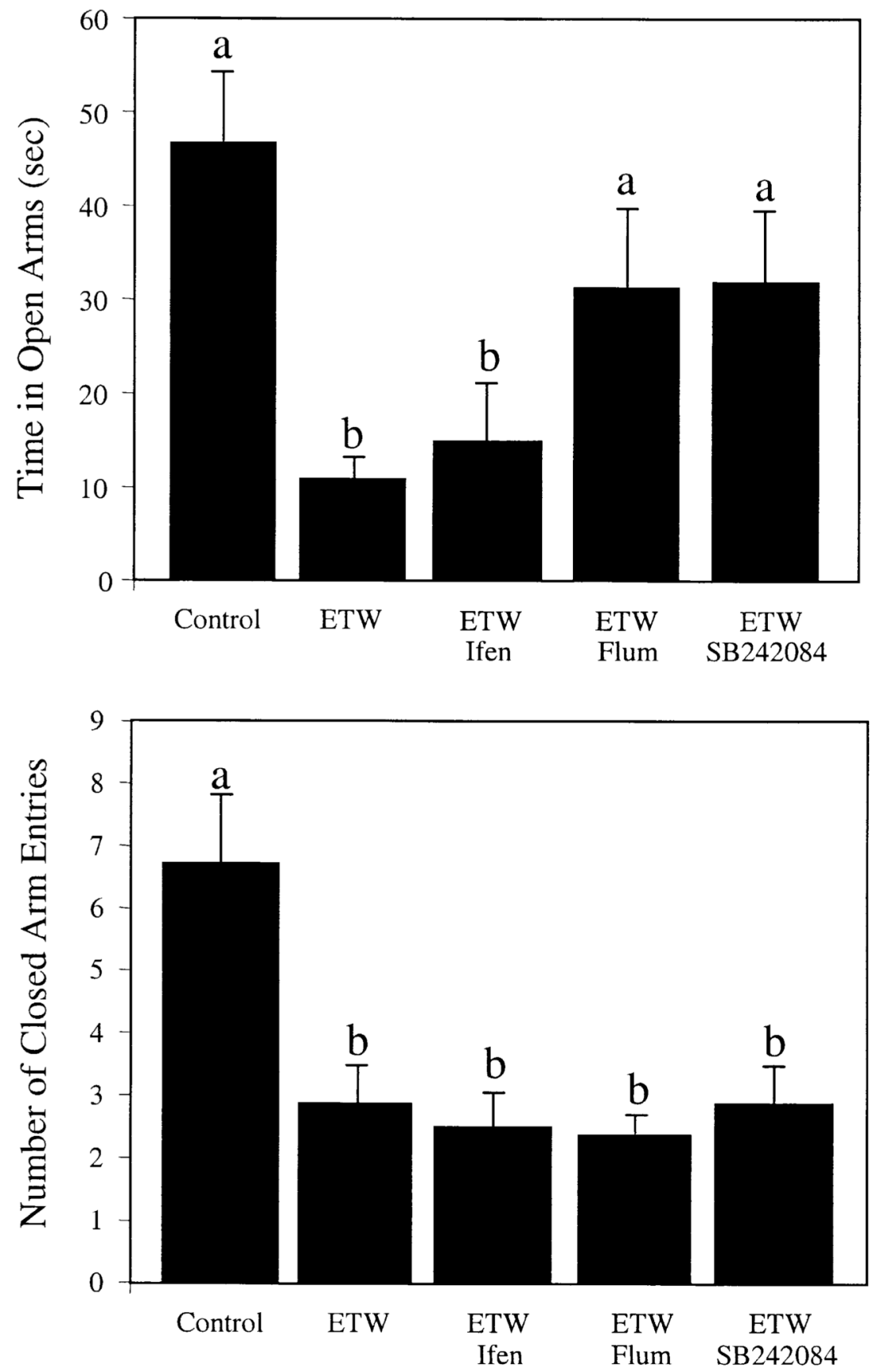

Fig. 3.

Mean time in open arms and number of closed-arm entries in the elevated plus-maze test of anxiety in ethanol-withdrawn (ETW) rats treated with vehicle [0.5\% solution of carboxymethylcellulose (CMC)], the benzodiazepine receptor antagonist flumazenil (Flum), the 5-hydroxytryptamine (serotonin) $2 \mathrm{C}\left(5-\mathrm{HT}_{2 \mathrm{C}}\right)$ receptor antagonist $\mathrm{SB} 242084$, or the $\mathrm{N}$ methyl-D-aspartate (NMDA)-type glutamate receptor antagonist ifenprodil (Ifen). Rats were treated for 17 days with 7\% (weight/volume) ethanol diet and tested between 5 and $6 \mathrm{~h}$ into withdrawal. Bars (means \pm S.E.M.) that do not share common letters are significantly different from each other $(P<.05)$. 

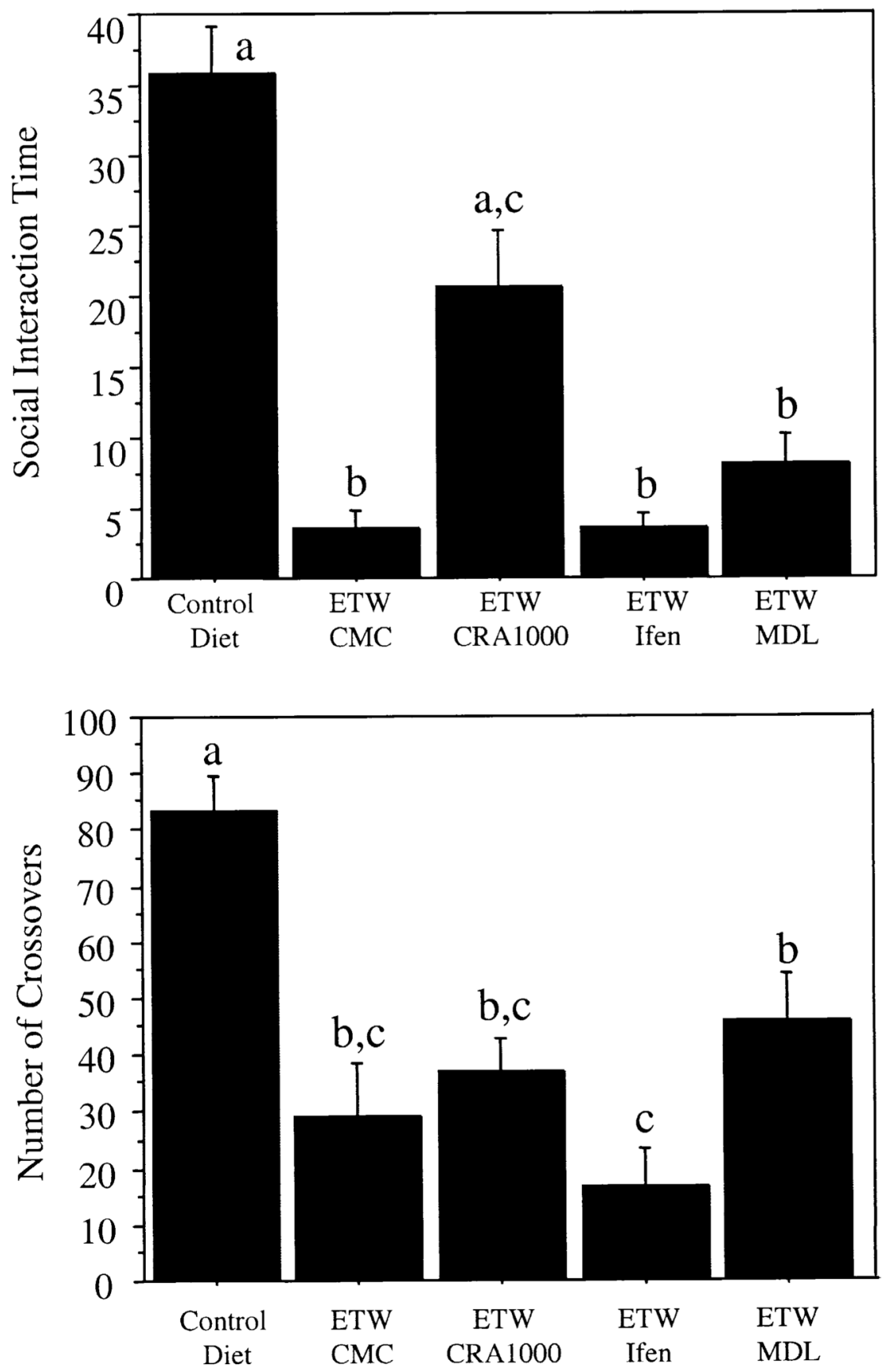

Fig. 4.

Mean social interaction time and locomotor activity scores for control and ethanol-withdrawn (ETW) rats treated with the 5-hydroxytryptamine (serotonin) $3\left(5-\mathrm{HT}_{3}\right)$ receptor antagonist MDL 72222 (MDL), the corticotropin-releasing factor (CRF) antagonist CRA1000, or the $\mathrm{N}$ methyl-D-aspartate (NMDA)-type glutamate receptor antagonist ifenprodil (Ifen). Rats were treated for 17 days with 7\% (weight/volume) ethanol diet and tested between 5 and $6 \mathrm{~h}$ into withdrawal. Bars (means \pm S.E.M.) that do not share common letters are significantly different from each other $(P<.05)$. CMC $=0.5 \%$ solution of carboxymethylcellulose vehicle. 

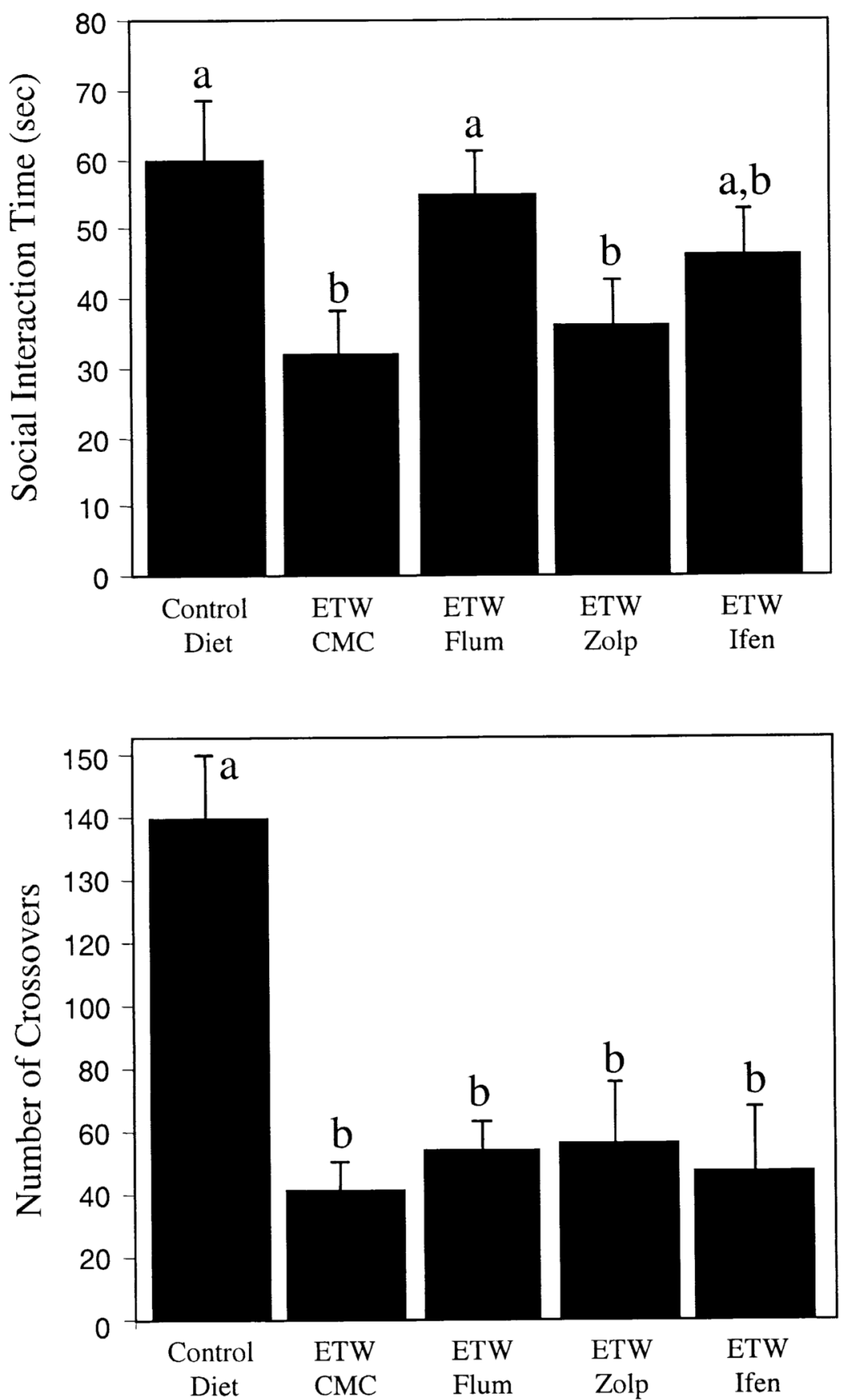

Fig. 5.

Mean social interaction time and locomotor activity scores for control and ethanol-withdrawn (ETW) rats treated with vehicle [0.5\% solution of carboxymethylcellulose (CMC)], the benzodiazepine receptor antagonist flumazenil (Flum), the benzodiazepine receptor agonist zolpidem (Zolp), and the $N$-methyl-D-aspartate (NMDA)-type glutamate receptor antagonist ifenprodil (Ifen). Rats were treated for 17 days with 7\% (weight/volume) ethanol diet and tested between 5 and $6 \mathrm{~h}$ into withdrawal. Bars (means \pm S.E.M.) that do not share common letters are significantly different from each other $(P<.05)$. 


\section{Table 1}

Effects of drugs that counteract withdrawal-induced social interaction deficits in control rats

\begin{tabular}{lll}
\hline Drug & Social interaction $(\mathrm{s})$ & Line crossings \\
\hline CMC vehicle $(1 \mathrm{ml} / \mathrm{kg})$ & $31.5 \pm 3.4$ & $116 \pm 12$ \\
$\mathrm{SB} 242084(1 \mathrm{mg} / \mathrm{kg})$ & $33.4 \pm 6.1$ & $129 \pm 16$ \\
CRA1000 $(1 \mathrm{mg} / \mathrm{kg})$ & $31.6 \pm 5.7$ & $121 \pm 17$ \\
Flumazenil $(5 \mathrm{mg} / \mathrm{kg})$ & $31.9 \pm 3.5$ & $85 \pm 12^{*}$ \\
Ifenprodil $(5 \mathrm{mg} / \mathrm{kg})$ & $13.6 \pm 3.2^{*}$ & $23 \pm 6^{*}$ \\
\hline
\end{tabular}

* Significantly different from values for CMC vehicle ( $0.5 \%$ solution of carboxymethylcellulose). 
Table 2

Acute dose-related effects of drugs on time spent in social interaction and line crossings in rats withdrawn from 17 days of $7 \%$ (weight/volume) ethanol diet

\begin{tabular}{|c|c|c|}
\hline Treatment & Social interaction (s) & Line crossings \\
\hline Control diet & $26.8 \pm 1.8$ & $95.9 \pm 9.3$ \\
\hline Ethanol diet & $8.8 \pm 1.8^{*}$ & $22.8 \pm 6.3^{*}$ \\
\hline \multicolumn{3}{|c|}{ Ifenprodil (mg/kg) } \\
\hline 2.5 & $13.9 \pm 3.7^{*}$ & $21.5 \pm 6.1^{*}$ \\
\hline 5.0 & $6.8 \pm 1.5^{*}$ & $22.7 \pm 7.0^{*}$ \\
\hline 10.0 & $8.3 \pm 2.4^{*}$ & $14.2 \pm 6.7^{*}$ \\
\hline \multicolumn{3}{|c|}{ Zolpidem (mg/kg) } \\
\hline 1.5 & $7.8 \pm 2.3^{*}$ & $12.3 \pm 6.8^{*}$ \\
\hline 3.0 & $12.5 \pm 4.1^{*}$ & $37.0 \pm 8.7^{*}$ \\
\hline \multicolumn{3}{|c|}{ MDL 72222 (mg/kg) } \\
\hline 0.3 & $14.3 \pm 3.6^{*}$ & $18.2 \pm 4.2^{*}$ \\
\hline 1.0 & $8.2 \pm 2.2^{*}$ & $26.0 \pm 5.6^{*}$ \\
\hline 3.0 & $12.3 \pm 5.7^{*}$ & $24.5 \pm 7.4^{*}$ \\
\hline \multicolumn{3}{|c|}{ Flumazenil (mg/kg) } \\
\hline 1.25 & $4.3 \pm 1.2^{*}$ & $23.8 \pm 6.7^{*}$ \\
\hline 2.50 & $16.5 \pm 1.8^{* * * *}$ & $36.5 \pm 10.0^{*}$ \\
\hline 5.00 & $22.8 \pm 3.0^{* *}$ & $36.1 \pm 5.5^{*}$ \\
\hline \multicolumn{3}{|c|}{ CRA1000 (mg/kg) } \\
\hline 0.25 & $13.0 \pm 3.0^{*}$ & $32.8 \pm 9.8^{*}$ \\
\hline 0.50 & $15.8 \pm 3.0^{* * * *}$ & $37.5 \pm 13.0^{*}$ \\
\hline 1.00 & $20.0 \pm 3.9^{*}, * *$ & $55.3 \pm 15.2^{*}$ \\
\hline \multicolumn{3}{|c|}{ SB242084 (mg/kg) } \\
\hline 0.25 & $6.0 \pm 2.9^{*}$ & $55.3 \pm 15.2^{*}$ \\
\hline 0.50 & $11.3 \pm 3.6^{*}$ & $26.7 \pm 6.2^{*}$ \\
\hline 1.00 & $21.5 \pm 2.1^{* *}$ & $52.0 \pm 19.5^{*}$ \\
\hline
\end{tabular}

